\title{
Spanish microgrids: current problems and future solutions
}

\author{
G. Fernández ${ }^{1}$, M. Trujilloº ${ }^{1}$ J. F. Sanz ${ }^{1,2}$, J. Sallán ${ }^{1,2}$ \\ ${ }^{1}$ Renewable Energy Integration Group \\ CIRCE Foundation, Zaragoza University \\ 2 Electrical Engineering Department. University of Zaragoza \\ CIRCE Building, Campus Río Ebro, C/ Mariano Esquillor Gómez, 15 - Zaragoza, 50018 Zaragoza (Spain) \\ Phone number: +0034 976 761863, Fax number: +0034 976 732078, \\ e-mail: gfa@unizar.es, trujillo@unizar.es, ifsanz@unizar.es, jsallan@unizar.es
}

\begin{abstract}
Some years ago microgrids ( $\mu$-grids) became the most promising solution to the problems of the current electric system. There are many studies that demonstrate the advantages of using $\mu$-grids, among which the following can be highlighted: microgrids can improve power quality inside and outside them; supply reliability of the internal loads is higher [1][2]; and the generalization of $\mu$-grids could extend the usage of distributed generation (DG) systems.
\end{abstract}

Despite being very extended in the scientific and engineering world, the $\mu$-grid concept is not usual in the ordinary world. Proof of this is that current electric legislation does not include their usage. Prior to its spread, $\mu$-grids must have an appropriate legal and economic environment. Through this text, the authors would like to show the legal limitations that the $\mu$-grids usage will find in Spain and the solutions that are applied in other countries and states.

The final objective of this paper is to present a legal and economic framework that would promote the development of $\mu$ grids in Spain.

\section{Key words}

Microgrids, Spanish Legislation, Economic framework, Feed-in Tariff, Net-metering.

\section{Introduction}

A microgrid is formed by a group of loads and microgenerators operating as a single system that provides electrical and thermal energy [3]. Another definition states that a $\mu$-grid is a network of low voltage (LV) consumers and producers able to export energy in some circumstances and also to work in an isolated way in emergency situations [4]. Attending only to the electrical part, we can define a $\mu$-grid as an electric system composed of generation and storage systems that feed a group of electric loads, which can work properly both isolated and grid-connected.

As it has been said, a $\mu$-grid has three groups of principal components: electric generators, storage systems and electric loads. There are no technical problems that prevent the joint operation of these devices but there is, in general, a lack of legislation to regulate their performance [5]. Even in some countries, like Spain, the joint use of DG systems (photovoltaics), storage equipment and electric loads is very limited and problematic.

An in-depth analysis of the Spanish electric and renewable energy legislation shows some aspects that limit and even prevent the use of $\mu$-grids. This document studies the most problematic articles of the Spanish regulation and looks for the solutions adopted in other countries.

Once the legislation allows the usage of $\mu$-grids, the next step would be the creation of an economic framework that provides a good profitability to these electric systems. This paper will analyse the economic regulation of other countries and a new economic framework will be proposed for Spain. This new economic framework will be analyzed and compared with the current Special Regime.

\section{Current configurations}

One of the main advantages of the usage of $\mu$-grids is that they use widely DG systems and renewable energies (RE). This has a disadvantage; DG and RE are more expensive than the classic systems used for generating electricity. For this reason, in Spain and in some other countries electricity generation from RE is legally and economically supported by the Government, within a legislation called "Regimen Especial de Generación de Energía Electrica” (Special Regime for Electricity Generation). The inclusion of $\mu$-grids in this regime is essential for their development.

As it has been said, $\mu$-grids and their architecture are not recognized by the Spanish regulation, so their development is very restricted. In the next paragraphs 
some $\mu$-grid configurations will be analyzed through the study of some laws:

- Real Decreto (RD) 661/2007, Special Regime for Electricity Generation [6].

- RD 1663/2000, Connection of photovoltaic facilities to the low voltage grid [7].

- RD 1995/2000, Regulation of transport, distribution, marketing and distribution activities and licensing procedures of electric facilities [8].

- RD 1578/2008, Remuneration of the activity of production of electric power by means of solar photovoltaic technology for facilities later to the deadline of maintenance of the remuneration of the RD 661/2007 [9].

- RD 1565/2010, Regulation and modification of certain aspects relative to the activity of production of electric power in special regime [10].

- RD 1614/2010, Regulation and modification of certain aspects relative to the activity of production of electric power from thermoelectric and wind technologies [11].

- RD-ley 14/2010, Urgent measures for the correction of the electrical sector tariff deficit. [12].

\section{A. 0 structure.}

The first analyzed situation (Fig 1) is not a real $\mu$-grid, since it does not include electric loads or storage systems, but it is considered because it serves as a starting point for the other configurations. This grid architecture could be inside the Special Regime if three conditions are met:

- The connection of the wind and photovoltaic generation systems must be performed between the metering devices and the distribution network.

- Legal power limitations due to the characteristics of the distribution network.

- The power of a photovoltaic generator connected to the low voltage grid is limited to $100 \mathrm{kVA}$.

\section{B. $0^{*}$ structure.}

In this situation electric loads are added to the previous $\mu$-grid. When the electric system is connected to the low voltage distribution network (Fig 2) three possible loads appear: loads 1 and 2 are completely legal but the third one puts the whole microgrid out of the Special Regime. If the $\mu$-grid is not capable of receiving the Special Regime tariff, its surplus energy should be sold in the ordinary regime, competing with cheaper and more efficient technologies.

When the $\mu$-grid is connected to a MV distribution network (Fig 3), four new possible loads appear, and all of them are legal. The four electric demands are allowed as far as the energy generated by every technology (wind and photovoltaic) and the one consumed by the loads are individually measured.

\section{1 structure.}

In this situation (Fig 4) the analyzed electric system is a complete $\mu$-grid, composed of electric generators, storage systems and electric loads. The electric system shown in figure 4 is completely legal if it incorporates a switching device that prevents the "critical load" from being simultaneously connected to the grid and to the generation and storage systems of the $\mu$-grid.

In this situation the critical loads can be fed, alternately and exclusively, from the distribution network or the generation and storage systems.
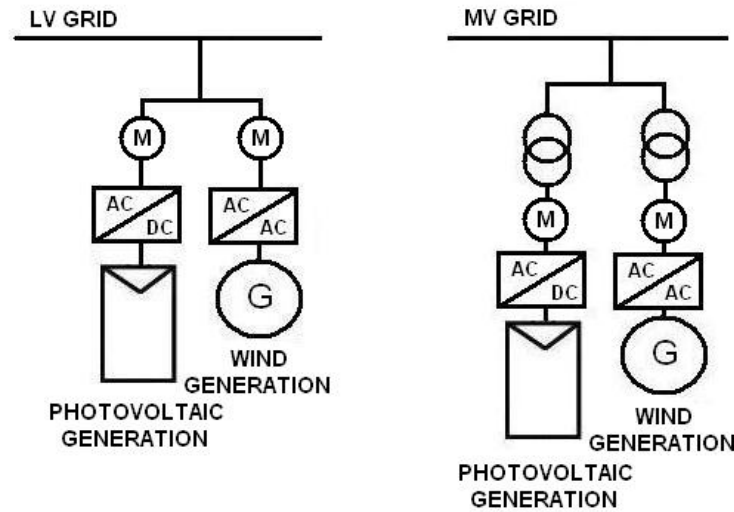

Fig. 1.0 structure for $\mu$-grids.
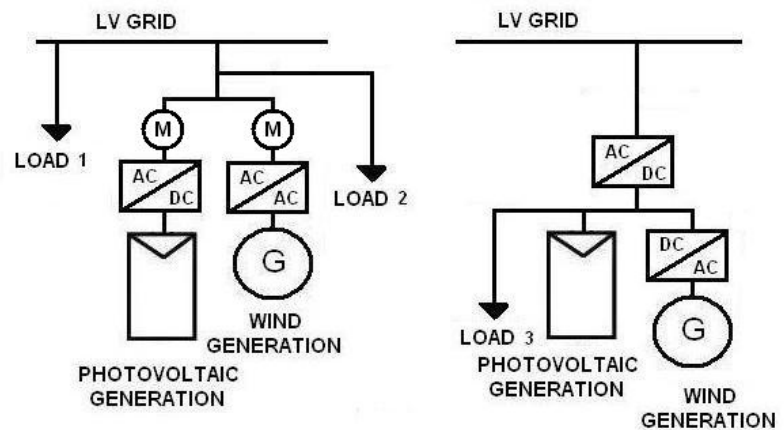

Fig. 2. 0* structure for $\mu$-grids connected to LV distribution networks.

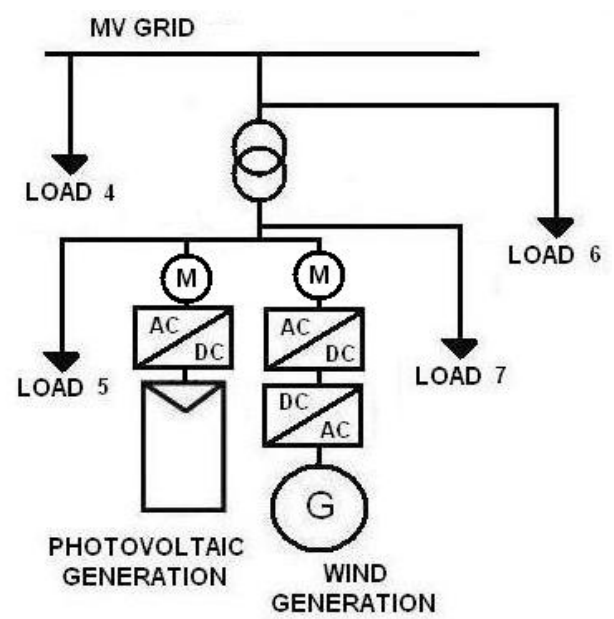

Fig. 3. $0^{*}$ structure for $\mu$-grids connected to MV distribution networks.

\section{2 structure}

Isolated $\mu$-grids (Fig. 5) are completely legal in the Spanish legislation. 


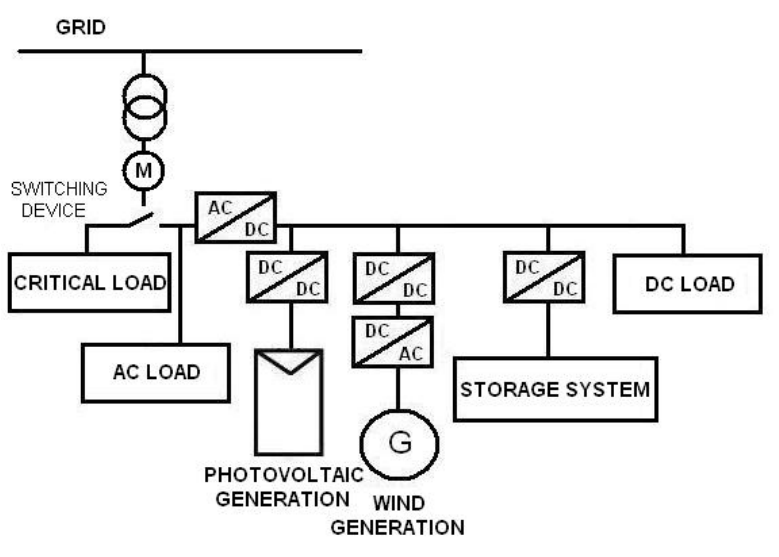

Fig. 4.1 structure for $\mu$-grids.

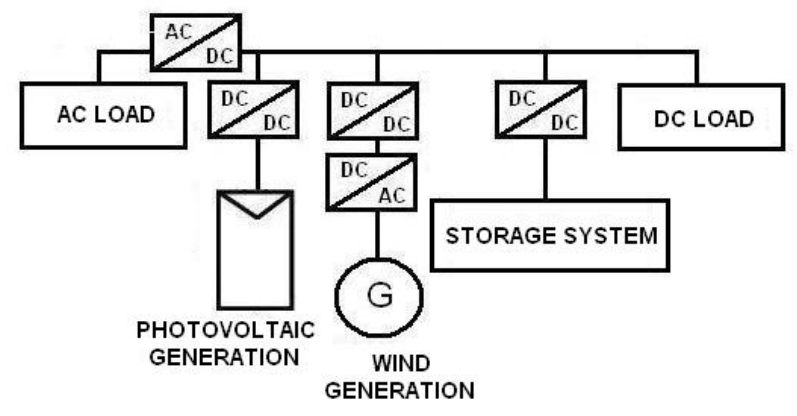

Fig. 5.2 structure for $\mu$-grids.

\section{E. 3 structure.}

This structure (Fig 6) represents the complete $\mu$-grid configuration. In these electric systems the loads are fed by the internal generation systems, and when the energy produced by them is insufficient, they are supported by the storage systems. If the storage and generation devices were insufficient to meet the electric demand, energy from the distribution network would be bought. In the opposite situation, the surplus energy generated inside the $\mu$-grid will be stored or sent to the distribution network.

This configuration is completely illegal for some reasons:

- Photovoltaic systems connected to the LV electric network can not be combined with other generation technologies, storage systems or electric loads connected between the solar panels and the metering devices. Electric loads and photovoltaic generators must be in independent circuits.

- Combination of wind and photovoltaic generation is not allowed.

- An electric consumer is not allowed to sell stored energy. He can become an electricity producer but not reseller.

\section{F. 4 structure.}

This situation (Fig 7) represents a residential community, where every neighbour has a $\mu$-grid and the whole electric system can be considered a microgrid (a microgrid made of smaller microgrids). This situation has the same legal problems as the previous one.
Summarizing, the main constrains that limit the development of $\mu$-grids in Spain are:

- Combination of wind and photovoltaic generation is not allowed (RD 661/2007, art. 23).

- In photovoltaic facilities connected to the low voltage grid installing electric loads, storage systems or other type of electric generation between the solar panels and the metering systems is not allowed (RD $1663 / 2000$, art. 8).

- Electric loads and photovoltaic generators must be in independent circuits with independent metering systems (RD 1663/2000, art. 10).

- The main reason that limits the expansion of $\mu$-grids in Spain is the current economic environment of the Special Regime, which promotes the sale of the whole generated energy instead of self-consumption.

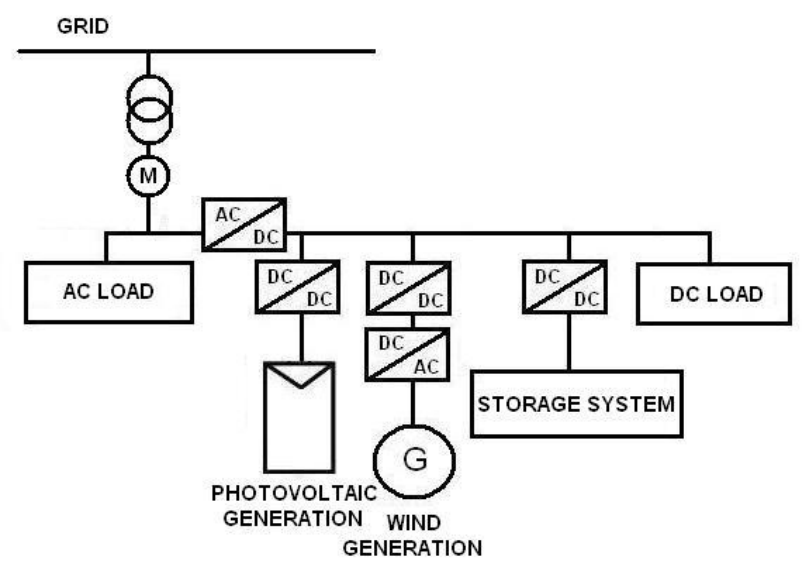

Fig. 6.3 structure for $\mu$-grids.

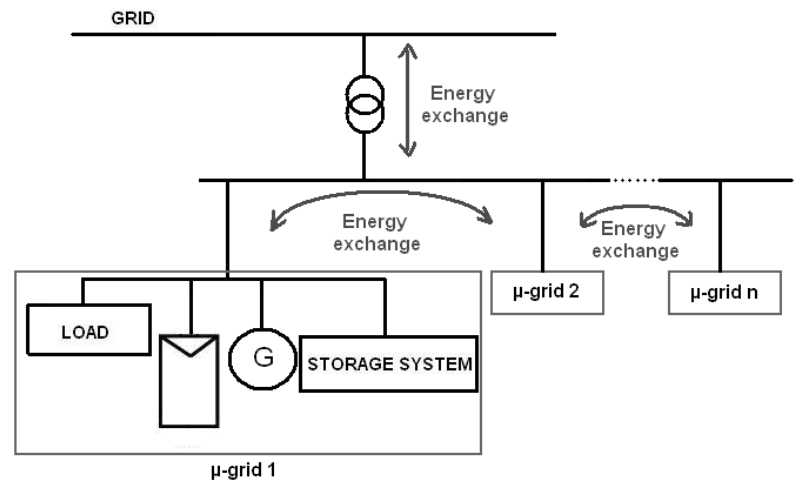

Fig. 7. 4 structure for $\mu$-grids.

\section{Possible solutions}

Once the limitations were discovered, other countries and states regulations (Portugal, United Kingdom, Germany, California, Ontario, Hawaii, Belgium, Italy and Japan) were analyzed in order to find some aspects that the Spanish legislation could adapt to promote the use of $\mu$ grids. These are the most interesting ones:

- Combination of renewable technologies must be allowed.

- Different kind of renewable energy generators must be allowed to be installed in the same place or building. Loads and generators should be in the same electric circuit.

- Allow the usage of electric storage systems. 
Other ways of promoting $\mu$-grids in other countries are:

- The bureaucracy required for installations under the special regime should be easier. In some countries, $\mu-$ grids connected to the low voltage single-phase networks only require a simple notification to the area distributor in order to be able to connect to the grid.

- Taxation of these facilities should be reduced or even removed.

- Combined turnover of the consumed and generated energy.

- Payment for the energy generated in the $\mu$-grid and consumed inside it.

\section{Proposed economic framework}

According to the analyzed legislation, a new economic framework will be proposed to promote the use of $\mu$ grids. This new framework will be based, as in Great Britain, in the Feed-in Tariff (FiT) and the Feed-in Compensation (FiC).

The FiT and FiC framework will be compared with others. The first one will be the current Spanish framework and the second will be the used in other countries for self-consuption: Net-metering.

\section{A. FiT and FiC framework.}

Through this text, a new economic framework, based on FiT and FiC tariff, will be proposed. In this context, the FiT is the money paid for the energy generated in the $\mu$ grid and sent to the electric network. The FiC is a compensation for the energy generated in the $\mu$-grid and consumed by it.

In this framework, the amount of the FiT and the FiC tariffs depends on the grid parity, the moment when the cost of the energy produced in the microgrid is the same as the energy bought from the electric grid. Before grid parity is achieved the microgrid owner will receive FiT and FiC tariffs and after grid parity is attained, only Feed-in Tariff (FiT). The FiC will be equal to the difference between the FiT and the cost of the energy from the electric grid, and the FiT could be imposed by the government.

The proposed FiT (Tables I to VII) will be calculated through the study of different environments where the objective is a proper profitability, which will be established between 6\% - 9\%. These environments have been defined using the Spanish National Electrotechnic Low Voltage Code [13]. Two different FiT will be established for every environment: one for the energy generated by the photovoltaic systems $\left(\mathrm{FiT}_{\mathrm{FV}}\right)$ and a second one for energy generated by the wind turbines $\left(\mathrm{FiT}_{\mathrm{W}}\right)$. The global Feed-in Tariff for the $\mu$-grid is calculated as a composition of both, FiT $_{\mathrm{FV}}$ and $\mathrm{FiT}_{\mathrm{W}}$, tariffs as shown in (1) and (2).

$$
F i T=\frac{F i T_{F V} * P_{F V}+F i T_{W} * P_{W}}{P_{G e n}}
$$

$$
P_{G e n}=P_{F V}+P_{W}
$$

Table I. Basic electrification flat (Domestic, $\mathrm{P}_{\mathrm{Gen}}<5 \mathrm{~kW}$ ).

\begin{tabular}{|l|l|}
\hline $\mathrm{FiT}_{\mathrm{FV}}$ & $\mathrm{FiT}_{\mathrm{W}}$ \\
\hline $40 \mathrm{c} / \mathrm{kWh}$ & $40 \mathrm{c} € / \mathrm{kWh}$ \\
\hline \multicolumn{2}{|c|}{$100 \%$ own founds. } \\
\hline
\end{tabular}

Table II. High electrification flat.

(Domestic, $5 \mathrm{~kW}<\mathrm{P}_{\mathrm{Gen}}<10 \mathrm{~kW}$ )

\begin{tabular}{|l|l|}
\hline FiT $_{\mathrm{FV}}$ & $\mathrm{FiT}_{\mathrm{W}}$ \\
\hline $37 \mathrm{c} € / \mathrm{kWh}$ & $37 \mathrm{c} € / \mathrm{kWh}$ \\
\hline \multicolumn{2}{|c|}{$100 \%$ own founds. } \\
\hline
\end{tabular}

Table III. Neighbors' community formed in a block of flats. (Domestic, $\mathrm{P}_{\mathrm{Gen}}>10 \mathrm{~kW}$ )

\begin{tabular}{|l|l|l|}
\hline \multicolumn{2}{|c|}{ (Domestic, $\left.\mathrm{P}_{\mathrm{Gen}}>10 \mathrm{~kW}\right)$} \\
\hline $31,4 \mathrm{c} € / \mathrm{kWh}$ & $\mathrm{FiT}_{\mathrm{W}}$ & Interest rate \\
\hline $34,3 \mathrm{c} / \mathrm{kWh}$ & $31,4 \mathrm{c} € / \mathrm{kWh}$ & $4 \%$ \\
\hline $50 \%$ own founds and $50 \%$ external founds; 12 years lending. \\
\hline $42,3 \mathrm{c} € / \mathrm{kWh}$ & $34,3 \mathrm{c} / \mathrm{kWh}$ & $6 \%$ \\
\hline \multicolumn{3}{|l|}{$100 \%$ own founds. } \\
\hline
\end{tabular}

Table IV. Neighbors' community formed by one-family housings. (Domestic, $\mathrm{P}_{\mathrm{Gen}}>10 \mathrm{~kW}$ )

\begin{tabular}{|l|l|l|}
\hline \multicolumn{4}{|c|}{ FiT $\mathrm{FiT}_{\mathrm{WV}}$} & Interest rate \\
\hline $29,2 \mathrm{c} € / \mathrm{kWh}$ & $29,2 \mathrm{c} / \mathrm{kWh}$ & $4 \%$ \\
\hline $31 \mathrm{c} € / \mathrm{kWh}$ & $31 \mathrm{c} € / \mathrm{kWh}$ & $6 \%$ \\
\hline $50 \%$ own founds and $50 \%$ external founds; 12 years lending; \\
\hline $40 \mathrm{c} € / \mathrm{kWh}$ & $40 \mathrm{c} € / \mathrm{kWh}$ & \\
\hline \multicolumn{3}{|c|}{$100 \%$ own founds. } \\
\hline
\end{tabular}

Table V. Commercial and offices buildings. (Comercial, $\mathrm{P}_{\mathrm{Gen}}>10 \mathrm{~kW}$ )

\begin{tabular}{|l|l|l|}
\hline $\mathrm{FiT}_{\mathrm{FV}}$ & $\mathrm{FiT}_{\mathrm{W}}$ & Interest rate \\
\hline $39,25 \mathrm{c} € / \mathrm{kWh}$ & $48,7 \mathrm{c} € / \mathrm{kWh}$ & $4 \%$ \\
\hline $40,95 \mathrm{c} / \mathrm{kWh}$ & $50,8 \mathrm{c} € / \mathrm{kWh}$ & $6 \%$ \\
\hline \multicolumn{3}{|l|}{$50 \%$ own founds and $50 \%$ external founds; 12 years lending; } \\
\hline $45 \mathrm{c} € / \mathrm{kWh}$ & $55,6 \mathrm{c} € / \mathrm{kWh}$ & \\
\hline \multicolumn{3}{|l|}{$100 \%$ own founds. } \\
\hline
\end{tabular}

Table VI. Industrial environments. (Industrial, $\mathrm{P}_{\mathrm{Gen}}>10 \mathrm{~kW}$ )

\begin{tabular}{|l|l|l|}
\hline $\mathrm{FiT}_{\mathrm{FV}}$ & $\mathrm{FiT}_{\mathrm{W}}$ & Interest rate \\
\hline $36,05 \mathrm{c} € / \mathrm{kWh}$ & $40,85 \mathrm{c} € / \mathrm{kWh}$ & $4 \%$ \\
\hline $37,7 \mathrm{c} € / \mathrm{kWh}$ & $42,55 \mathrm{c} € / \mathrm{kWh}$ & $6 \%$ \\
\hline \multicolumn{3}{|l|}{$50 \%$ own founds and $50 \%$ external founds; 12 years lending; } \\
\hline $41,55 \mathrm{c} € / \mathrm{kWh}$ & $46,5 \mathrm{c} € / \mathrm{kWh}$ & \\
\hline \multicolumn{3}{|l|}{$100 \%$ own founds. } \\
\hline
\end{tabular}

\begin{tabular}{|c|c|c|}
\multicolumn{4}{|c}{ Table VII. Global FiT. } \\
\hline & FiT $_{\mathrm{FV}}[\mathrm{c} € / \mathrm{kWh}]$ & FiT $_{\mathrm{W}}[\mathrm{c} € / \mathrm{kWh}]$ \\
\hline $\begin{array}{c}\text { Domestic, } \\
\mathrm{P}_{\mathrm{Gen}}<5 \mathrm{~kW}\end{array}$ & 40 & 40 \\
\hline $\begin{array}{c}\text { Domestic, } \\
5 \mathrm{~kW}<\mathrm{P}_{\mathrm{Gen}}<10 \mathrm{~kW}\end{array}$ & 37 & 37 \\
\hline $\begin{array}{c}\text { Domestic, } \\
\mathrm{P}_{\mathrm{Gen}}>10 \mathrm{~kW}\end{array}$ & $29,2-42,3$ & $29,2-42,3$ \\
\hline $\begin{array}{c}\text { Comercial, } \\
\mathrm{P}_{\mathrm{Gen}}>10 \mathrm{~kW}\end{array}$ & $39,25-45$ & $48,7-55,6$ \\
\hline $\begin{array}{c}\text { Industrial, } \\
\mathrm{P}_{\mathrm{Gen}}>10 \mathrm{~kW}\end{array}$ & $36,05-41,55$ & $40,85-46,5$ \\
\hline
\end{tabular}

The study has been made with the component costs shown in Table VIII and the economic framework shown in Table IX. 
Table VIII. Global FiT.

\begin{tabular}{|c|c|}
\hline Photovoltaic Generator & $2,5 € / \mathrm{W}$ \\
\hline $\begin{array}{c}\text { Wind Generator } \\
(1 \mathrm{~kW}<\mathrm{P}<5 \mathrm{~kW})\end{array}$ & $2,6 € / \mathrm{kW}$ \\
\hline $\begin{array}{c}\text { Wind Generator } \\
(5 \mathrm{~kW}<\mathrm{P}<200 \mathrm{~kW})\end{array}$ & $3,1 € / \mathrm{kW}$ \\
\hline Batteries & $300 € / \mathrm{kWh}$ \\
\hline Converter & $0,7 € / \mathrm{W}$ \\
\hline
\end{tabular}

Table IX. Economical analysis parameters.

\begin{tabular}{|c|c|}
\hline $\begin{array}{c}\text { Economic investment } \\
\text { lifetime }\end{array}$ & 20 years \\
\hline Inflation & $3 \%$ \\
\hline Discount rate & $4 \%$ \\
\hline Lending interests & 4 y 6\% \\
\hline Taxes & $\begin{array}{c}\text { Companies tax (20\% ó 25\%) } \\
\text { or IRPF (18\%) }\end{array}$ \\
\hline Tax deduction & None \\
\hline Financing & $\begin{array}{c}10 \% \text { yearly (industrial and } \\
\text { commercial environments). } \\
\text { Without amortization in } \\
\text { domestic environments. }\end{array}$ \\
\hline Amortization & Variable (inflation updated) \\
\hline Operation and maintenance
\end{tabular}

\section{B. Comparison with other economic frameworks.}

In this paragraph, the proposed FiT and FiC framework will be compared with several versions of the Spanish Special Regime and the Net-metering method used in other countries (Tables X to XIII). The current Spanish Special Regime is based on Feed-in Tariffs (FiT) for the whole energy generated by the photovoltaic or wind systems.

In other countries and states, like Italy or Ontario, the Net-Metering is the economic framework. There are two variants of the Net-Metering framework: in the first one, the surplus energy is paid with a Feed-in Tariff and in the second one, the $\mu$-grid owner can get, free of charge, the same energy amount that has been produced in the microgrid and sent to the electric grid. The comparison between the economic frameworks will be performed through some of the environments used to establish the FiT and FiC tariffs.

\section{Economic conclusions.}

Several conclusions have been reached from the previous paragraphs:

- In spite of the fact that the current Spanish economic framework could be more profitable than the proposed one, the cost for the electric system is much lower in the new one.

- The proposed FiT and FiC framework is more profitable than the Net-Metering.

- A significant part of the $\mu$-grid incomings in the proposed economic framework comes from the savings in the electrical invoice. An important consequence is that an increase in the electrical invoice improves the $\mu$-grid profitability.

- Due to the increase of initial cost that supposes the construction of $\mu$-grids on the current photovoltaic and wind facilities, the correct location of the photovoltaic panels and wind turbines is fundamental in order to maximize the energy production.

- The proportion between the power of the electric wind and photovoltaic generators will depend on the natural resources of the zone of implantation of the $\mu$ grid.

Table X. Basic electrification flat. (Domestic, $\mathrm{P}_{\mathrm{Gen}}<5 \mathrm{~kW}$ )

\begin{tabular}{|c|c|c|c|}
\cline { 2 - 4 } \multicolumn{1}{c|}{} & $\begin{array}{c}\text { FiT and FiC } \\
\text { framework } \\
\text { (FiT=40 } \\
\text { c } € / \text { /Wh) }\end{array}$ & $\begin{array}{c}\text { Spanish } \\
\text { Special } \\
\text { Regime (RD } \\
1578 / 2008)\end{array}$ & $\begin{array}{c}\text { Spanish Special } \\
\text { Regime } \\
\text { (RD1565/2010) }\end{array}$ \\
\hline VNA [€] & $3.373,22$ & $5.910,79$ & $5.027,68$ \\
\hline IRR [\%] & 8.28 & 10,00 & 9,25 \\
\hline $\begin{array}{c}\text { PAY-BACK } \\
\text { [years] }\end{array}$ & 12 & 12 & 13 \\
\hline $\begin{array}{c}\text { Electric bill } \\
\left(1^{\text {st }} \text { year) [€] }\right.\end{array}$ & $1.588,03$ & $2.155,134$ & $2.155,134$ \\
\hline $\begin{array}{c}\text { Incomings } \\
\left(1^{\text {st }} \text { year) [€] }\right.\end{array}$ & $1.668,36$ & $1.281,3$ & $1.217,24$ \\
\hline $\begin{array}{c}\text { System } \\
\text { expenses } \\
\left(1^{\text {st }} \text { year) [€] }\right.\end{array}$ & $1.132,03$ & $1.281,3$ & $1.217,24$ \\
\hline $\begin{array}{c}\text { Incomings } \\
\left(8^{\text {th }} \text { year) [€] }\right.\end{array}$ & 814,37 & $1.523,06$ & $1.446,91$ \\
\hline $\begin{array}{c}\text { System } \\
\text { expenses } \\
\left(8^{\text {th }} \text { year) [€] }\right.\end{array}$ & 104,29 & $1.523,06$ & $1.446,91$ \\
\hline $\begin{array}{c}\text { Total system } \\
\text { expenses (in } \\
\text { the initial } \\
\text { moment) [€] }\end{array}$ & $8.144,33$ & $21.539,24$ & $20.462,28$ \\
\hline
\end{tabular}

Table XI. Basic electrification flat. (Domestic, $\mathrm{P}_{\mathrm{Gen}}<5 \mathrm{~kW}$ ).

\begin{tabular}{|c|c|c|c|}
\cline { 2 - 4 } \multicolumn{1}{c|}{} & $\begin{array}{c}\text { Spanish Special } \\
\text { Regime } \\
\text { (RD1565/2010 y } \\
\text { RD-ley 14/2010) }\end{array}$ & $\begin{array}{c}\text { Net-metering } \\
\text { (With FiT=40 } \\
\text { c } / \text { /WWh }\end{array}$ & $\begin{array}{c}\text { Net- } \\
\text { metering } \\
\text { (Without } \\
\text { FiT) }\end{array}$ \\
\hline VNA [€] & $4.795,22$ & $-2.083,29$ & $-2.191,96$ \\
\hline IRR [\%] & 8,96 & 1,79 & 1,67 \\
\hline $\begin{array}{c}\text { PAY-BACK } \\
\text { [years] }\end{array}$ & 13 & $>20$ & $>20$ \\
\hline $\begin{array}{c}\text { Electric bill } \\
\left(1^{\text {st }} \text { year) [€] }\right.\end{array}$ & $2.155,134$ & $1.588,03$ & $1.518,19$ \\
\hline $\begin{array}{c}\text { Incomings } \\
\left(1^{\text {st }} \text { year) [€] }\right.\end{array}$ & $1.068,75$ & 621,13 & 606,48 \\
\hline $\begin{array}{c}\text { System expenses } \\
\left(1^{\text {st }} \text { year) [€] }\right.\end{array}$ & $1.068,75$ & 84,80 & 0 \\
\hline $\begin{array}{c}\text { Incomings } \\
\left(8^{\text {th }} \text { year) [€] }\right.\end{array}$ & $1.446,91$ & 814,37 & 802,95 \\
\hline $\begin{array}{c}\text { System expenses } \\
\left(8^{\text {th }} \text { year) [€] }\right.\end{array}$ & $1.446,91$ & 104,29 & 0 \\
\hline $\begin{array}{c}\text { Total system } \\
\text { expenses (in the } \\
\text { initial moment) } \\
\text { [€] }\end{array}$ & $20.462,28$ & $1.490,06$ & 0 \\
\hline
\end{tabular}

- The way of financing the project is very important in its profitability. The proportion between own and external funds, the interest rate and the period of return of the lending can improve the profitability of the $\mu$-grid. Some countries offer soft credits or subsidies for the construction of $\mu$-grid.

- A consequence of the fact that the more powerful the installations are, the most profitable will be, is that the generation systems power should be limited. In some countries, the generation systems power is limited to the electric power (all or a fraction) contracted with the distribution company. In other countries there is not a real power limitation, but in fact this is limited by the Net-Metering economic framework. 
- The FiT should be updated yearly according to the inflation evolution.

- The FiT for new installations should be reduced yearly a fixed percentage to include the effect of technology improvements and future installations cost reduction. This could be a way of promoting the $\mu$ grids technological development.

- Other interesting aspects derived from the microgrid use are power quality and electric network reliability improvements. Although these are difficult to evaluate economically, in [4] and [14] an evaluation method is proposed.

Table XII. High electrification flat.

\begin{tabular}{|c|c|c|c|}
\hline & $\begin{array}{c}\text { FiT and FiC } \\
\text { framework } \\
(\mathrm{FiT}=37 \\
\mathrm{c} € / \mathrm{kWh}) \\
\end{array}$ & $\begin{array}{c}\text { Spanish Special } \\
\text { Regime (RD } \\
\text { 1578/2008 y RD } \\
661 / 2007) \\
\end{array}$ & $\begin{array}{c}\text { Spanish Special } \\
\text { Regime (RD } \\
\text { 1565/2010 y RD } \\
661 / 2007 \text { ) } \\
\end{array}$ \\
\hline VNA [€] & $8.156,34$ & $9.001,18$ & $7.268,26$ \\
\hline IRR [\%] & 7,67 & 7,51 & 6,94 \\
\hline $\begin{array}{c}\text { PAY-BACK } \\
\text { [years] }\end{array}$ & 14 & 15 & 15 \\
\hline $\begin{array}{l}\text { Electric bill } \\
\left(1^{\text {st }} \text { year }\right)[€]\end{array}$ & $4.758,56$ & $6.064,11$ & $6.064,11$ \\
\hline $\begin{array}{c}\text { Incomings } \\
\left(1^{\text {st }} \text { year }\right)[€]\end{array}$ & $4.038,19$ & $2.709,28$ & $2.583,56$ \\
\hline $\begin{array}{c}\text { System } \\
\text { expenses } \\
\left(1^{\text {st }} \text { year }\right)[€]\end{array}$ & $2.732,65$ & $2.709,28$ & $2.583,56$ \\
\hline $\begin{array}{c}\text { Incomings } \\
\left(8^{\text {th }} \text { year }\right)[€]\end{array}$ & $2.316,86$ & $3.205,11$ & $3.055,67$ \\
\hline $\begin{array}{c}\text { System } \\
\text { expenses } \\
\left(8^{\text {th }} \text { year }\right)[€]\end{array}$ & 588,38 & $3.205,11$ & $3.055,67$ \\
\hline $\begin{array}{l}\text { Total system } \\
\text { expenses (in } \\
\text { the initial } \\
\text { moment) }[€]\end{array}$ & $22.675,25$ & $45.271,64$ & 43.158,31 \\
\hline
\end{tabular}

Table XIII. High electrification flat.

(Domestic, $5 \mathrm{~kW}<\mathrm{P}_{\mathrm{Gen}}<10 \mathrm{~kW}$ ).

\begin{tabular}{|c|c|c|c|}
\multicolumn{1}{c|}{} & \multicolumn{1}{c|}{$\left(\right.$ Domestic, 5kW $\left.<\mathrm{P}_{\text {Gen }}<10 \mathrm{~kW}\right)}$. \\
\cline { 2 - 4 } & $\begin{array}{c}\text { Spanish Special } \\
\text { Regime (RD } \\
1565 / 2010, \mathrm{RD} \\
661 / 2007 \text { y RD-ley } \\
14 / 2010)\end{array}$ & $\begin{array}{c}\text { Net-metering } \\
\text { (With } \\
\text { FiT=37 } \\
\text { c€/kWh) }\end{array}$ & $\begin{array}{c}\text { Net- } \\
\text { metering } \\
\text { (Without } \\
\text { FiT) }\end{array}$ \\
\hline VNA [€] & $6.875,17$ & $-3.544,15$ & $-5.962,11$ \\
\hline IRR [\%] & 6,77 & 2,62 & 1,62 \\
\hline $\begin{array}{c}\text { PAY-BACK } \\
\text { [years] }\end{array}$ & 16 & $>20$ & $>20$ \\
\hline $\begin{array}{c}\text { Electric bill } \\
\left(1^{\text {st }} \text { year) [€] }\right.\end{array}$ & $6.064,11$ & $4.758,56$ & $4.472,55$ \\
\hline $\begin{array}{c}\text { Incomings } \\
\left(1^{\text {st }} \text { year) [€] }\right.\end{array}$ & $2.332,48$ & $1.783,96$ & $1.587,56$ \\
\hline $\begin{array}{c}\text { System } \\
\text { expenses (1 } \\
\text { year) [€] }\end{array}$ & $2.332,48$ & 478,41 & 0 \\
\hline $\begin{array}{c}\text { Incomings } \\
\left(8^{\text {th }} \text { year) [€] }\right.\end{array}$ & $3.055,67$ & $2.316,86$ & $2.101,84$ \\
\hline $\begin{array}{c}\text { System } \\
\text { expenses (8) } \\
\text { year) [€] }\end{array}$ & $3.055,67$ & 606,04 & 0 \\
\hline $\begin{array}{c}\text { Total system } \\
\text { expenses (in the } \\
\text { initial moment) } \\
{[€]}\end{array}$ & $42.678,94$ & $8.406,35$ & 0 \\
\hline
\end{tabular}

\section{Conclusion.}

Microgrids are technically viable, but in Spain are limited by legal aspects: combination of different technologies is not allowed; photovoltaic generators can not be joined with electric loads, storage systems or other generators in installations connected to the low voltage grid; and the sale of energy is promoted by the economic framework, instead of self-consumption. These problems could be solved, as in other countries, adapting the current legislation to the $\mu$-grid concept and creating a new economic framework based in FiT and FiC tariffs.

\section{References}

[1] S. Papathanassiou, D. Georgakis, N. Hatziaqyriou, A. Engler, C. Hardt, "Operation of a prototype Micro-grid system based on micro-sources equipped with fast-acting power electronics interfaces”, IEEE PESC 2004 Aachen Germany, 2004.

[2] S. Morozumi, "Micro-grids Demonstration Projects in Japan”, PCC (Power Conversion Conference) 2007, Nagoya, Japan, 2007.

[3] R.H. Lasseter, "MicroGrids" IEEE Power Engineering Society Winter Meeting, 2002. Volume 1, 27-31 Jan. 2002 Page(s):305 - 308 vol.1.

[4] P.M. Costa, M.A. Matos, "Assessing contribution of microgrids to the reliability of distribution networks", Electric Power Systems Research (2009), num 79, pp. 382389.

[5] J.A.P. Lopes, "Management of microgrids”, International Electric Equipment Conference, Bilbao, 2003.

[6] Real Decreto 661/2007, May 25 ${ }^{\text {th }}$, Special Regime for Electricity Generation.

[7] Real Decreto $1663 / 2000$, September $29^{\text {th }}$, Connection of photovoltaic facilities to the low voltage grid.

[8] Real Decreto 1995/2000, December $1^{\text {st }}$, Regulation of transport, distribution, marketing and distribution activities and licensing procedures of electric facilities.

[9] Real Decreto $1578 / 2008$, September $26^{\text {th }}$, of remuneration of the activity of production of electric power by means of solar photovoltaic technology for facilities later to the deadline of maintenance of the remuneration of the Royal decree 661/2007.

[10] Real Decreto $1565 / 2010$, November $19^{\text {th }}$, by which there are regulated and modify certain aspects relative to the activity of production of electric power in special regime.

[11] Real Decreto 1614/2010, December $7^{\text {th }}$, Regulation and modification of certain aspects relative to the activity of production of electric power from thermoelectric and wind technologies.

[12] Real Decreto-ley 14/2010, December $23^{\text {th }}$, by which urgent measures are established for the correction of the electrical sector tariff deficit.

[13] Spanish National Electrotechnic Low Voltage Code (Reglamento Electrotécnico de Baja Tensión, in spanish). Approved by Real Decreto 842/2002.

[14] P. M. Costa, M. A. Matos, "Economic Analysis of Microgrids Including Reliability aspects", International Conference on Probabilistic Methods Applied to Power Systems, IEEE, 2006. 